\title{
An unusual case of pneumocephalus
}

\author{
P Bhogal, ${ }^{1}$ G Bhatnagar, ${ }^{2} \mathrm{~J}$ Manieson, ${ }^{3}$ T Booth, ${ }^{1}$ C Prendergast ${ }^{3}$
}

1Department of Radiology, Royal Free Hospital, London, UK;

2Department of Radiology, Plymouth Hospital, Plymouth, UK;

${ }^{3}$ Department of Radiology, Lister Hospital, Stevenage, UK

Correspondence to Dr Pervinder Bhogal, bhogalweb@aol.com

\section{Summary}

The authors present an unusual cause of pneumocephalus in a previously fit and well female octogenarian who presented with acute onset altered level of consciousness and generalised weakness. Radiological imaging demonstrated widespread cerebritis with pneumocephalus and gas within the superior sagittal sinus. Blood culture grew Clostridium septicum, a virulent but rare organism that can infect normal tissues. The close association between $C$ septicum and both haematological and bowel malignancies must be considered if this organism is cultured.

\section{BACKGROUND}

This condition is very rare.

No previous cases of Clostridium septicum related pneumocephalus in the past 35 years at the admitting institution (Lister Hospital, Stevenage).

$C$ septicum infection can result in fatality rapidly; therefore, correct diagnosis and treatment is required urgently.

$C$ septicum infections are associated with both bowel and haematological malignancies.

\section{CASE PRESENTATION}

Our patient was a normally fit and healthy lady who lived alone and was independent in activities of daily living. She suffered from hypertension, stable angina and non-insulin dependant type II diabetes mellitus.

She presented to the emergency department having been found with an altered level of consciousness and generalised weakness by her son. History from the relatives revealed that she had been suffering from diarrhoea and vomiting for 3 days.

On arrival to the emergency department, her Glasgow Coma Scale was 9 (E4, M4, V1). Clinical examination demonstrated marked neck stiffness, limb weakness and equivocal plantar response. She was in atrial fibrillation but otherwise had a normal cardiovascular and abdominal examination. On arrival in the emergency department, her blood pressure was $177 / 76 \mathrm{~mm} \mathrm{Hg}$, pulse 87 , apyrexial with respiratory rate of 20 and saturating at $95 \%$ on 151 of oxygen. Her blood glucose was $12 \mathrm{mmol} / \mathrm{l}$.

\section{INVESTIGATIONS}

Blood tests revealed a normocytic anaemia (haemoglobin $9.5 \mathrm{~g} / \mathrm{dl}$, mean cell volume $90 \mathrm{fl}$ ), raised white cell count of $38.5\left(\times 10^{9} / 1\right)$ with neutrophil count of $27.6\left(\times 10^{9} / 1\right)$. She was thrombocytopaenic with platelet count of 49 $\left(\times 10^{9} / 1\right)$, raised fibrinogen $(13 \mathrm{~g} / 1$, normal $2-4 \mathrm{~g} / \mathrm{l})$ and normal international normalised ratio. The $\mathrm{C}$ reactive protein was $464 \mathrm{mg} / \mathrm{l}$. Liver function tests, electrolytes and albumin were normal but her renal function tests showed urea $21.2 \mathrm{mmol} / \mathrm{l}$ and creatinine $179 \mathrm{mmol} / \mathrm{l}$. Recent blood tests conducted 1 month earlier were all normal except for the anaemia. Blood, stool and urine samples were sent for microscopy, culture and sensitivity. A chest radiograph performed in the department was normal.

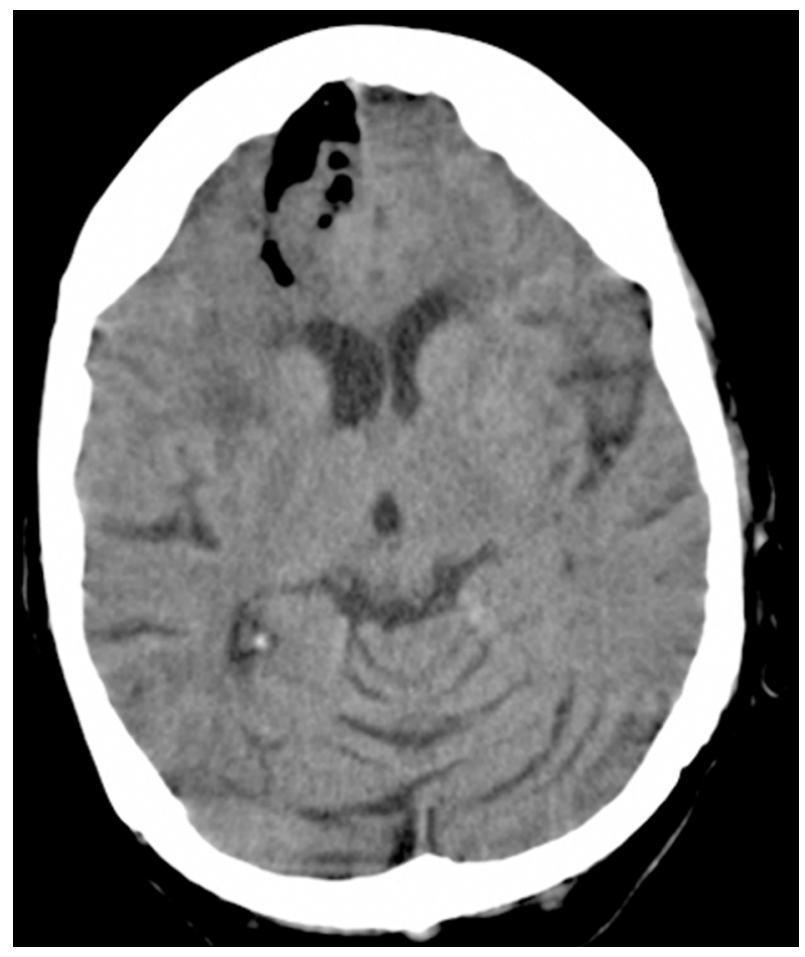

Figure 1 A large pocket of air can be seen in the right frontal lobe in a parafalcine position. There is a small amount of surrounding oedema but no mass effect. 


\section{BMJ Case Reports}

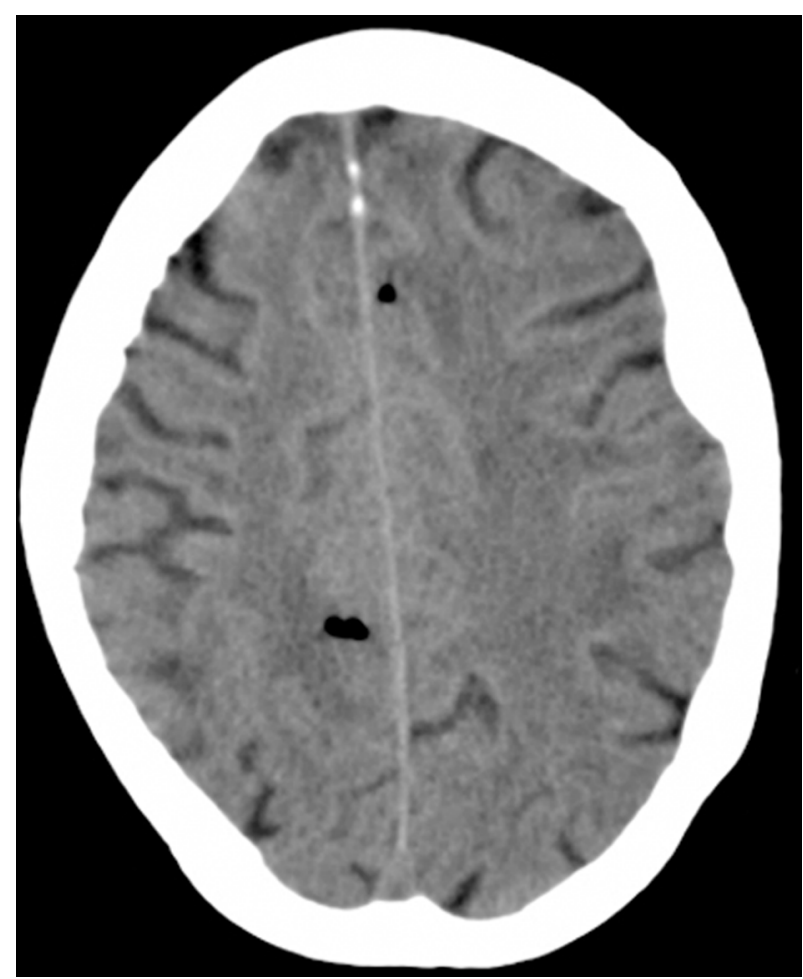

Figure 2 Several smaller pockets of intraparenchymal air were seen throughout the rest of the brain. No fractures were seen.

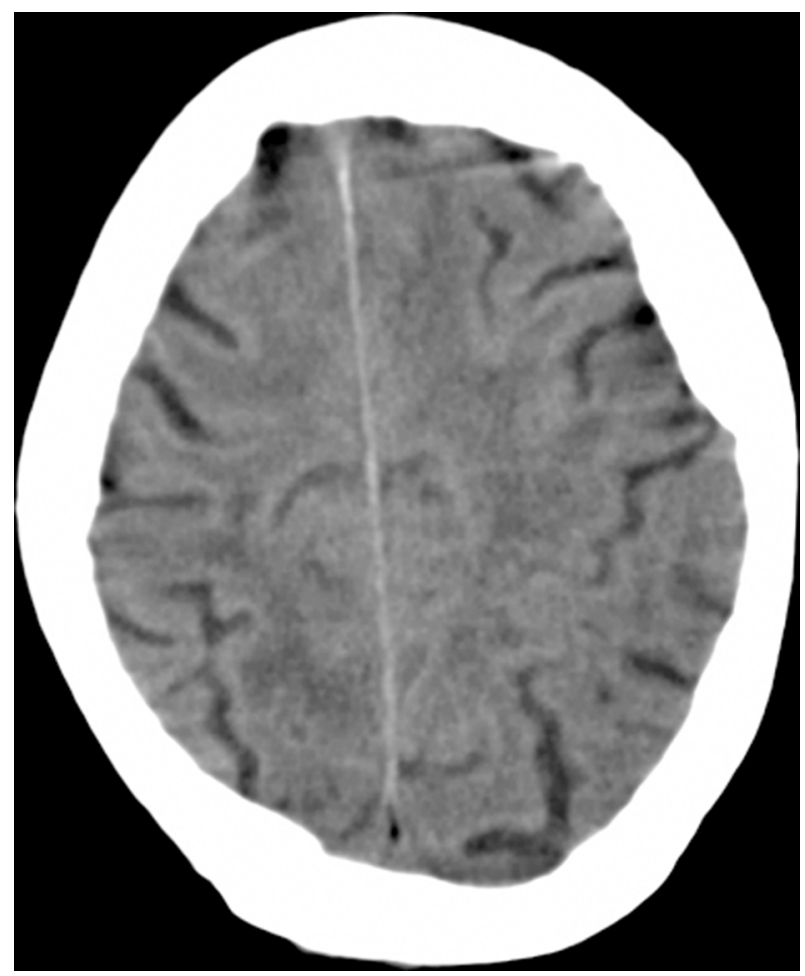

Figure 3 Air was also seen in the sagittal sinus.

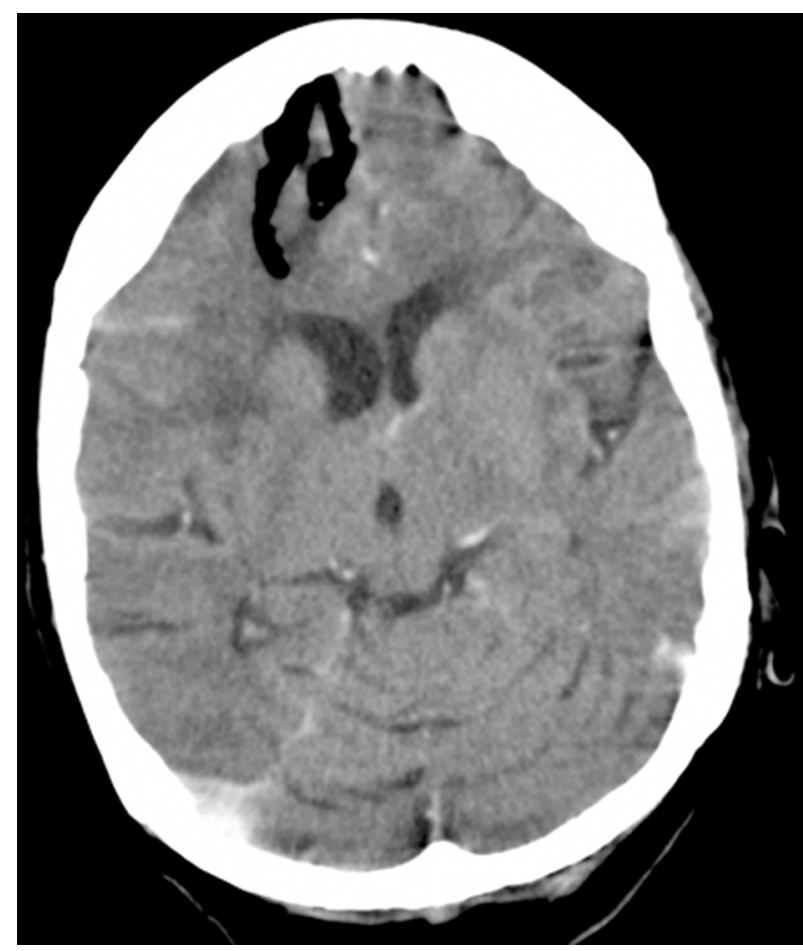

Figures 4 Demonstrate no significant contrast enhancement of the surrounding tissue.

Approximately $1 \mathrm{~h}$ after arrival in the emergency department, a CT head scan was performed.

\section{DIFFERENTIAL DIAGNOSIS}

Brain abscess secondary to Escherichia coli, Enterobacter cloacae and Klebsiella aerogenes (figures 1-5).

\section{TREATMENT}

She was started on intravenous cefotaxime and metronidazole.

\section{OUTCOME AND FOLLOW-UP}

Shortly after the CT scan, the patient went into cardiorespiratory arrest and died. C septicum was grown from the blood samples $48 \mathrm{~h}$ later.

\section{DISCUSSION}

Our patient presented with generalised weakness and altered consciousness and was found to have pneumocephalus and positive blood cultures. The most common causes for intracranial gas are trauma and surgical intervention. Infection by gas-forming organisms is a rare cause, ${ }^{12}$ and further infrequent causes include congenital defects, neoplastic erosion of the skull base, barotrauma and radiotherapy to the base of the skull. In a review of 295 cases, the causes for pneumocephalus were found to be secondary to trauma in $73 \%$, tumours in $12.9 \%$, surgical intervention in $8.8 \%$ and unknown in $0.6 \% .^{3}$ 
Details of the several previous causes are given below:

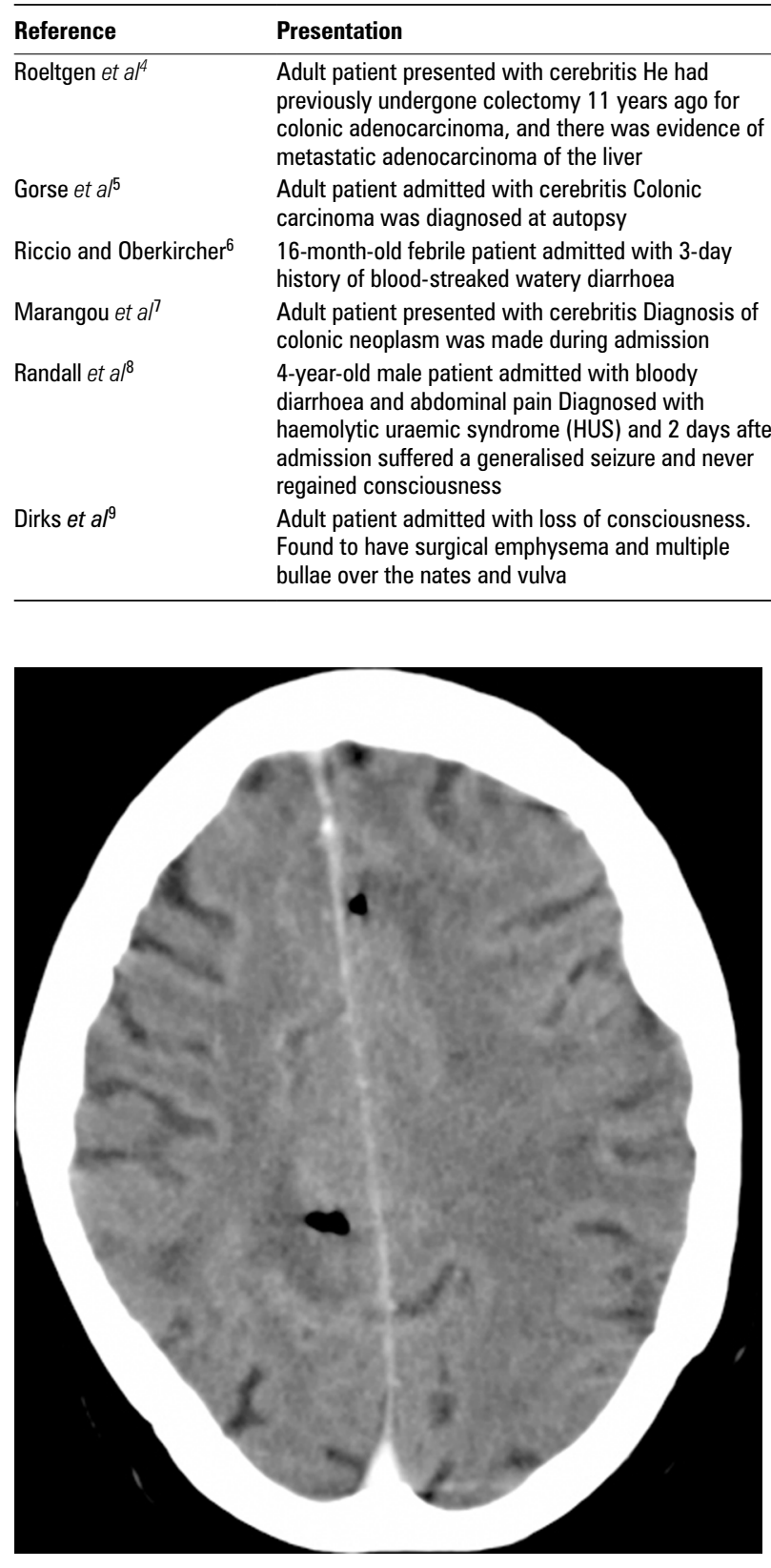

Figure 5 Demonstrate no ring enhancement.

C septicum is an anaerobic, gas producing, gram positive, spore-forming bacillus. It is more aerotolerant than other members of the clostridia family and is, hence, hardier and able to infect normal tissues. It appears to have a fulminant course and is usually associated with malignancy. ${ }^{2}$ The organism can produce an exotoxin that is able to hydrolyse cell membranes and cause tissue necrosis by inducing occlusive microvascular thrombosis. ${ }^{10}$ The ability of $C$ septicum to infect normal tissue and its aggressive nature

\begin{tabular}{|c|c|}
\hline Management & Outcome \\
\hline Managed with intravenous antibiotics & Died within $24 \mathrm{~h}$ of admission \\
\hline Managed with intravenous antibiotics & Died within $24 \mathrm{~h}$ of admission \\
\hline $\begin{array}{l}\text { Fluid resuscitation was required before } \\
\text { haemodialysis could be started }\end{array}$ & $\begin{array}{l}\text { Died approximately } 48 \mathrm{~h} \text { after hospital } \\
\text { admission }\end{array}$ \\
\hline Neurosurgical debridement and drainage & Died 16 days after admission \\
\hline
\end{tabular}

of necrotic tissue and antibiotic therapy

Treatment as appropriate for HUS

Ventilator therapy was withdrawn $5 \mathrm{~h}$ after generalised seizure

Admitted to ITU

Patient dies $8 \mathrm{~h}$ after admission to hospital

can produce startling changes in the clinical condition of patients.

C septicum has been found in 10-63\% of normal appendices, ${ }^{11}$ and it is believed that the terminal ileum and caecum may provide the most favourable environment in the human gastrointestinal tract for colonisation. ${ }^{10}$ It is believed that when the bowel mucosal barrier is compromised through colitis, neutropaenia or perforating colon cancers, a portal exists for entry of the organism into the blood stream and seeding at distant sites. ${ }^{12}$ This is the proposed theory behind the association of $C$ septicum infection and gastrointestinal malignancy.

Infections with $C$ septicum are rare and comprise only $1.3 \%$ of all clostridial infections. ${ }^{13}$ It is an important pathogen not only because of its strong association with malignancy but also because of its high mortality. The mortality for infection with $C$ septicum can be as high as $70 \%,{ }^{2}$ and in one study that looked at all clostridial infections, the mortality was found to be $56 \%$ from $C$ septicum compared to $26 \%$ from other strains. ${ }^{14}$ Other bacterial organisms that can cause pneumocephalus include $E$ coli, E cloacae and $K$ aerogenes. ${ }^{15}$

The mainstay of treatment is with intravenous antibiotics, principally penicillins. Patients with $C$ septicum infection should also undergo investigation to exclude malignancy, primarily gastrointestinal or haematological in origin.

Our case serves as a reminder of this rare but grave disease and again emphasises the rapidness with which patients can deteriorate.

\section{Learning points}

C septicum is rapidly fatal if not treated with appropriate antibiotics - penicillins.

- It is associated with both bowel and haematological malignancies.

- The organism can survive in well-oxygenated tissues. 


\section{BMJ Case Reports}

\section{Competing interests None.}

Patient consent Not obtained.

\section{REFERENCES}

1. Sebald M, Hauser D. Pasteur, oxygen and the anaerobes revisited. Anaerobe 1995;1:11-16.

2. MacLennan JD. The histotoxic clostridial infections of man. Bacteriol Rev 1962;26:177-276.

3. Markam JW. Clinical features of pneumocephalus based upon a survey of 284 cases with report of 11 additional cases. Acta Neurochir (Wien) 1967;16:1-78.

4. Roeltgen D, Shugar G, Towfighi J. Cerebritis due to Clostridium septicum. Neurology 1980:30:1314-16.

5. Gorse GJ, Slater LM, Sobol E, et al. CNS infection and bacteremia due to clostridium septicum. Arch Neurol 1984;41:882-4.

6. Riccio JA, Oberkircher OR. Clostridium septicum sepsis and cerebritis: a rare complication of the hemolytic-uremic syndrome. Pediatr Infect Dis $J$ 1988; 7:342-5.

7. Marangou AG, Joske RA, Kaard AO, et al. Cerebral abscess due to Clostridium septicum. J R Soc Med 1992;85:641.
8. Randall JM, Hall K, Coulthard MG. Diffuse pneumocephalus due to Clostridium septicum cerebritis in haemolytic uraemic syndrome: CT demonstration. Neuroradiology 1993;35:218-20.

9. Dirks C, Horn H, Christensen L, et al. CNS infection with clostridium septicum. Scand J Infect Dis 2000;32:320-2.

10. Khan AA, Davenport K. A reminder of the association between Clostridium septicum and colonic adenocarcinoma. Int Semin Surg Oncol 2006;3:12.

11. George WL, Finegold SM. Clostridia in the human gastrointestinal flora. In: Borriello SP, ed. Clostridia in Gastrointestinal Disease. Boca Raton, FL: CRC Press 1985:1-37.

12. Sailors DM, Eidt JF, Gagne PJ, et al. Primary Clostridium septicum aortitis: a rare cause of necrotizing suprarenal aortic infection. A case report and review of the literature. J Vasc Surg 1996;23:714-18.

13. Bodey GP, Rodriguez $S$, Fainstein $V$, et al. Clostridial bacteremia in cancer patients. A 12-year experience. Cancer 1991;67:1928-42.

14. Pelfrey TM, Turk RP, Peoples JB, et al. Surgical aspects of Clostridium septicum septicemia. Arch Surg 1984;119:546-50.

15. Tanaka T, Takagi D, Takeyama N, et al. "Spontaneous" pneumocephalus associated with aerobic bacteremia. Clin Imaging 1989;13:134-9.

This pdf has been created automatically from the final edited text and images.

Copyright 2011 BMJ Publishing Group. All rights reserved. For permission to reuse any of this content visit http://group.bmj.com/group/rights-licensing/permissions.

BMJ Case Report Fellows may re-use this article for personal use and teaching without any further permission.

Please cite this article as follows (you will need to access the article online to obtain the date of publication).

Bhogal P, Bhatnagar G, Manieson J, Booth T, Prendergast C. An unusual case of pneumocephalus. BMJ Case Reports 2011;10.1136/bcr.06.2010.3106, date of publication

Become a Fellow of BMJ Case Reports today and you can:

- Submit as many cases as you like

- Enjoy fast sympathetic peer review and rapid publication of accepted articles

- Access all the published articles

- Re-use any of the published material for personal use and teaching without further permission

For information on Institutional Fellowships contact consortiasales@bmjgroup.com

Visit casereports.bmj.com for more articles like this and to become a Fellow 